\title{
Price Adjustment Process for Rental Office Space ${ }^{1}$
}

\author{
James D. Shilling \\ Louisiana State \\ C. F. Sirmans \\ Louisiana State \\ John B. Corgel \\ Georgia State University
}

This paper analyzes the price adjustment process for rental office space in 17 cities across the United States over the time period 1960 to 1975 . The results confirm much of what economic theory suggests. Landlords react to fluctuations in demand by building up or drawing down inventories of unlet or vacant office space. Other things equal, higher levels of vacant office space mean that landlords lower their rents and reduce the difference between desired and actual vacancies. Empirical evidence is also presented on the normal vacancy rate across different cities.

\section{INTRODUCTION}

The price-inventory adjustment process represents a classic problem in economics. Normally, firms respond to increases in demand for their products either by increasing production and keeping prices constant or by making small quantity adjustments and large price changes. ${ }^{2}$ When a firm's output is "inventoriable," however, these observations change dramatically. Blinder [4] shows that firms holding inventories tend to exhibit smaller price and output responses to changes in demand and

\footnotetext{
${ }^{1}$ We acknowledge helpful comments from Peter Colwell, Jim Barth, John Clapp, Mel Jameson, an anonymous reviewer, and faculty workshops at the University of South Carolina and Louisiana State University.

${ }^{2}$ The presence of uncertainty has been shown to cause single-period monopolistic firms to lower price and increase output; see Mills [19] and Karlin and Carr [15]. For related discussions, see Blinder [4], Baron [3], Leland [16], and Zabel [29]. Recent examinations of the short-run dynamics of price and output and of inventory cycles are contained in Maccini [18], Phlips [21], Blinder and Fischer [5], and Pindyck [22].
} 
that the magnitude of these changes depends on the marginal cost of holding inventory. Firms with sharply rising marginal inventory costs respond to changes in demand with large price and output movement and small reliance on inventories as buffer stocks. Conversely, firms with relatively constant marginal costs of inventory holding rely heavily on inventory changes and little on changes in prices and output.

The analogy to the rental market for commercial office space is straightforward. Landlords react to fluctuations in demand either by building up or drawing down inventories of unlet office space or by adjusting rents. Rent (i.e., price) adjustments should be the strongest when the gap between the normal, long-run vacancy rate and the actual vacancy rate is the largest, and weakest when vacancies exceed the normal rate. Conceptually, this requires that there be a desired inventory of vacant office space that landlords are willing to hold. Theory suggests that this desired level of vacancies affords landlords flexibility in dealing with fluctuations in demand and turnover of tenants. Due to the relatively long life of office leases, landlords hold vacant office space in inventory to capitalize on opportunities to supply units at higher rentals during periods of increasing demand. ${ }^{3}$

In this paper we test how firms respond to demand shocks by examining the rental adjustment process for the U.S. commercial office market. ${ }^{4}$ Using revenue and expense data for office buildings in 17 cities,

\footnotetext{
${ }^{3}$ The literature on the office building market has examined primarily the spatial aspects. See, for example, Hamer [14], Clapp [10], Archer [2], and Tauchen and Witte [28], Recent literature has also developed standard hedonic gradients for office rents. An example of this literature is Brennan et al. [6].

${ }^{4}$ Several authors have examined the price-adjustment process in the rental housing market. Smith [27] has tested the process for Canadian cities. In other research, the importance of holding vacancies in determining the dynamic adjustment of rents and output to demand shocks has been shown to be minimal (deLeeuw and Ekanem [11]; Eubank and Sirmans [12]; Lowry [17]). Capozza [8] suggests that the reason for the conflicting evidence on the importance of vacancies in the rental price-adjustment process is due primarily to specification error. His results for Los Angeles County indicate that vacancies are an important explanatory variable for predicting changes in rents. More recently, Rosen and Smith [24] present evidence supporting behavior when markets are in disequilibrium. They suggest that variations in the vacancy rate around a long-run normal vacancy rate lead landlords to
} 
we show that investment in vacant office space can be viewed as a means of acquiring flexibility in reacting to unanticipated events. Furthermore, we show that differences in the marginal costs of carrying inventory across cities as well as expected fluctuations in demand help to explain variations in the normal vacancy rate.

\section{COMMERCIAL OFFICE RENT-ADJUSTMENT PROCESS}

Following the discussion of Alchian and Allen [1], an inventory of vacant office space is not necessarily a wasted good. Since office space is produced in advance at a less rapid and therefore more economical rate, and because an inventory of vacant space is held in case demand increases at random times, both landlords and tenants economize. To cover the costs of vacancies held by landlords, the price per unit of the flow of services from office space may be somewhat higher. Vacancies allow lower search cost and enable tenants to move without committing themselves long in advance. The market could reduce the price of rental space by building fewer office buildings and thus having fewer vacancies. This would force tenants to plan well in advance and prevent them from adapting quickly to new situations. We expect that, on average, the inventory of empty office space that enables tenants to conveniently search for and move into different offices is small. ${ }^{5}$

Theory also suggests that the stochastic nature of these demand

charge less and reduce planned investment in order to bring markets back into equilibrium. Furthermore, they explain differences in the normal vacancy rate across cities by differences in uncertainty surrounding demand conditions. In general, their results can be interpreted as being consistent with the idea that prices move sluggishly in industries whose outputs are inventoriable and where fluctuations in demand are relatively large. This assumes that the market is unaffected by either price or rent controls. For an analysis of rent controls in the market for apartment units, see Fallis and Smith [13], and Olsen [20].

5 Alchian and Allen [1, p. 89] argue that about $3 \%$ of the rent paid by apartment dwellers covers the cost of vacant apartment space. The empirical results of Rosen and Smith [24] indicate a fairly high normal vacancy rate for apartments in various U.S. cities. Their estimates indicate a median rate of $9.8 \%$. 
shocks should have two possible effects on landlord pricing behavior. For landlords whose costs of carrying inventories rise rapidly when they have excessive vacancies, both price and output decisions should display small short-run adjustments as planned inventory holdings react strongly to inventory disequilibrium. Other things equal, higher levels of vacant office space mean that landlords should lower their rents and reduce the difference between desired and actual vacancies. However, for landlords whose inventory cost functions are nearly constant, the level of vacant office space is not critical. These landlords are better suited to waiting things out and to leasing properties under more favorable conditions. ${ }^{6}$

On an industry-wide basis, reaction to demand shocks and the relationship between rent adjustments and vacancies are uncertain. Following Smith [27] and Rosen and Smith [24], we posit

$$
R=r\left(E, V^{n}-V\right)
$$

where $R$ and $E$ denote the rates of change in rents and total operating expenses, respectively, $V$ is the observed vacancy rate, and $V^{n}$ is the desired vacancy rate. In this framework, if expected demand were perfectly anticipated, the desired change in vacancies would equal zero. By definition, the initial level of vacancies for which this occurs defines $V^{n}$. Deviations in the actual vacancy rate from the desired vacancy rate should elicit a partial adjustment of inventory holdings and exert pressure on rents until in equilibrium excess demand is zero. The nominal rate of change in office rents should also respond to changes in total operating expenses if landlords are successful in passing all or part of their costs on to tenants. ${ }^{7}$

\footnotetext{
${ }^{6}$ Commercial office space is leased in units of varying size, usually for 1 to 5 years. Most lease contracts require considerable negotiation and typically contain a rent escalation clause. The recent movement toward shorter terms and more net leases has helped office building landlords respond quickly to changes in demand. Still the demand by many firms for prestige space means that a substantial amount of rented space is always being turned over and must be released. For a discussion of recent changes in the leases for office space, see Shenkel [26].

${ }^{7}$ This assumes that commercial leases are gross leases or perhaps a percentage lease coupled with what is in essence a gross lease. Gross leases provide that the tenant pays a flat sum. Out of this, the
} 
Making the assumptions that (1) is linear and that landlords expect future vacancy rates to tend toward a normal level of vacancies that can be estimated on the basis of past experiences, (1) becomes

$$
R=b_{0}+b_{1} E-b_{2} V
$$

where $b_{0}=b_{2} V^{n}$, and $b_{1} \sim 1$. An estimate of $V^{n}$ can be obtained if it is assumed that the desired vacancy rate is constant. We also allow for nonconstant slopes by using an interaction term. ${ }^{8}$ Since the risk from holding commercial real estate increases as vacancies increase, an interaction term comprised of the rate of change in rents times the vacancy rate is entered into the regression equation to control for scale effects.

Before proceeding to the empirical work, we make two points about the rent-adjustment process in (2). First, the natural vacancy hypothesis has proved to be difficult to test. The theory suggests that vacancies and rents may be determined jointly. ${ }^{9}$ The main difficulties in testing this relationship have involved collecting data on the cost of holding inventories. Second, the rent-adjustment process may also be influenced by taxes. ${ }^{10}$ To the extent that tax changes and operating expenses are not highly correlated, estimates of (2) will be unbiased.

landlord gets to keep what remains after paying all operating expenses. Alternatively if the lease agreement is a net lease, where the tenant pays all expenses and gives the landlord a flat fee, then rents should be unaffected by changes in operating expenses. This varies depending on the degree of "netness."

${ }^{8}$ For a theoretical discussion of the effects of using interaction terms in empirical research, see Cassidy [9].

${ }^{9}$ As a practical matter, even though the estimated equation is a part of a simultaneous-equations model, ordinary least squares results in efficient estimates so long as the computed $R^{1}$ is close to unity (see Rao and Miller [23]). Given that the $R^{1}$ 's for our rent equations are greater than 0.90 for most cities, potential simultaneous-equation bias should not be present.

${ }^{10}$ The idea that taxes influence the level of rents is consistent with the central relationship between the demand for capital and the "user cost" of capital. A fundamental aspect of this relationship, which generally has not been examined in empirical work on the topic, is to test the effect of information about taxes and depreciation rates on the desired vacancy rate. We note that, if the lease agreement is a net lease, then rents may be unaffected by property taxes. 


\section{RENTS AND VACANCIES}

To test the relationship between price changes and vacancies, (2) is estimated using annual data on office buildings for 17 cites from 1960 to 1975. ${ }^{11}$ All data are taken from the "Experience Exchange Report" [7] published by Building Owners and Managers Association (BOMA) International. The report includes data on general offices, medical offices, singlepurpose offices, and corporate headquarters. The sample is restricted to buildings located in a central business district as determined by BOMA International. Size of the average office building ranges from under 50,000 to over 600,000 square feet.

The data on office rental income, $R$, and operating expense, $E$, are unweighted averages of rental cost per square foot of office space and total operating costs per square foot, respectively. ${ }^{12}$ Rental income includes all rent received from office space, ground floor stores, basement areas, and special areas. Operating expenses consist of cleaning, electrical, heating and cooling, administrative, minor alterations and normal periodic cleaning and decorating of offices, and total fixed charges, such as real estate taxes and insurance.

The vacancy variable, $V$, is calculated from the average office occupancy reported for each building. Trends in the vacancy variable suggest that during the last several years of the estimation period, vacancy rates moved to the older properties as leasing activities improved for newer buildings. Single-occupancy buildings, defined as being $51 \%$ or more occupied by a single tenant, also had a significantly lower vacancy rate when compared with an identical building, similar in all respects except for single tenancy.

\footnotetext{
${ }^{11}$ The cities are Atlanta, Baltimore, Chicago, Cleveland, Denver, Des Moines, Detroit, Indianapolis, Kansas City, Minneapolis, New York City, Philadelphia, Pittsburgh, Portland, San Francisco, Seattle, and Spokane. Beginning after 1975, the data are not consistent with the earlier period.

${ }^{12}$ Both $R$ and $E$ are defined in real, rather than nominal, terms by deflating each variable using the consumer price index (CPI).
} 


\section{Regression Results}

The results from estimating (2) after ascribing an error term of the ordinary sort to the specification are presented in Table 1. Standard errors (reported in parentheses under the regression coefficients), the coefficient of determination, the standard error of the equation, and the Durbin-Watson statistic for each equation are shown. All equations were estimated using ordinary least squares. ${ }^{13}$

The expense variable $E$ enters with an insignificant coefficient in all equations except those for Cleveland, Detroit, Indianapolis, and Kansas City. The results suggest that because office space is extremely inventoriable, any increase in cost may simply reduce the desired level of inventories while leaving prices relatively unchanged. Thus depending on the shadow price of holding vacant units, price changes may be associated with strong output responses rather than with weak ones.

It is not surprising, therefore, to find that the vacancy variable $V$ was significant at or above the $90 \%$ level in explaining changes in net rents for 11 of the 17 cities. In all cities the vacancy variable had the correct sign. ${ }^{14}$ The interaction term between vacancies and the rate of change in rents also proved to be a key determinant of $R$. For all cities the coefficient of the interaction variable had the expected sign and was significant. Taken collectively, holding vacancies has two principal effects on landlord

\footnotetext{
${ }^{13} \mathrm{An}$ examination of the Durbin-Watson statistics suggests that the null hypothesis of no first-order serial correlation can be rejected for most equations. A Cochrane-Orcutt transformation was used for equations exhibiting serial correlation, but the results are not reported here since the generalized least-squares estimate of the constant term in this case makes the calculation of the natural vacancy rate difficult.

${ }^{14}$ To test the hypothesis that institutional constraints on the pricing behavior of landlords create a complex lag structure between rents and inventory holdings of vacant office space, lagged values of $V$ were entered into the regression equations. The results indicated that the coefficient of the lagged vacancy variable had the appropriate sign, but was insignificant.
} 
TABLE 1

Commercial Office Building Price-Adjustment Equations, 1960-1975

\begin{tabular}{|c|c|c|c|c|c|c|c|}
\hline City & Constant & $\dot{E}$ & $V$ & Interaction & $R^{2}$ & $D-W$ & SSE \\
\hline Atlanta & $\begin{array}{c}0.126 \\
(0.026)\end{array}$ & $\begin{array}{c}-0.081 \\
(0.115)\end{array}$ & $\begin{array}{c}-1.995 \\
(0.431)\end{array}$ & $\begin{array}{l}15.520 \\
(1.990)\end{array}$ & 0.89 & 2.446 & 0.013 \\
\hline Baltimore & $\begin{array}{c}0.048 \\
(0.035)\end{array}$ & $\begin{array}{c}-0.124 \\
(0.138)\end{array}$ & $\begin{array}{c}-0.345 \\
(1.162)\end{array}$ & $\begin{array}{l}22.777 \\
(5.077)\end{array}$ & 0.72 & 1.960 & 0.045 \\
\hline Chicago & $\begin{array}{c}0.071 \\
(0.013)\end{array}$ & $\begin{array}{r}-0.022 \\
(0.034)\end{array}$ & $\begin{array}{r}-1.754 \\
(0.365)\end{array}$ & $\begin{array}{l}22.752 \\
(7.512)\end{array}$ & 0.81 & 2.772 & 0.003 \\
\hline Cleveland & $\begin{array}{c}0.036 \\
(0.011)\end{array}$ & $\begin{array}{c}0.149 \\
(0.052)\end{array}$ & $\begin{array}{c}-1.271 \\
(0.327)\end{array}$ & $\begin{array}{l}32.051 \\
(2.517)\end{array}$ & 0.95 & 1.963 & 0.002 \\
\hline Denver & $\begin{array}{c}0.045 \\
(0.030)\end{array}$ & $\begin{array}{r}-0.049 \\
(0.067)\end{array}$ & $\begin{array}{c}-0.365 \\
(0.318)\end{array}$ & $\begin{array}{c}9.008 \\
(0.847)\end{array}$ & 0.93 & 1,986 & 0.012 \\
\hline Des Moines & $\begin{array}{c}0.055 \\
(0.041)\end{array}$ & $\begin{array}{c}-0.378 \\
(0.290)\end{array}$ & $\begin{array}{c}-0.555 \\
(1.126)\end{array}$ & & 0.66 & 1.090 & 0.042 \\
\hline Detroit & $\begin{array}{c}0.029 \\
(0.007)\end{array}$ & $\begin{array}{c}0.038 \\
(0.020)\end{array}$ & $\begin{array}{c}-0.246 \\
(0.131)\end{array}$ & $\begin{array}{l}14.126 \\
(0.721)\end{array}$ & 0.98 & 2.247 & 0.001 \\
\hline Indianapolis & $\begin{array}{c}0.046 \\
(0.016)\end{array}$ & $\begin{array}{c}0.130 \\
(0.064)\end{array}$ & $\begin{array}{c}-0.711 \\
(0.241)\end{array}$ & $\begin{array}{l}15.614 \\
(1.865)\end{array}$ & 0.91 & 2.950 & 0.004 \\
\hline Kansas City & $\begin{array}{c}0.028 \\
(0.019)\end{array}$ & $\begin{array}{c}0.215 \\
(0.094)\end{array}$ & $\begin{array}{r}-0.134 \\
(0.167)\end{array}$ & $\begin{array}{c}5.748 \\
(1.130)\end{array}$ & 0.88 & 1.300 & 0.013 \\
\hline Minneapolis & $\begin{array}{c}0.034 \\
(0.006)\end{array}$ & $\begin{array}{c}0.039 \\
(0.032)\end{array}$ & $\begin{array}{c}-0.759 \\
(0.139)\end{array}$ & $\begin{array}{l}23.341 \\
(2.274)\end{array}$ & 0.92 & 1.863 & 0.001 \\
\hline New York City & $\begin{array}{c}0.063 \\
(0.022)\end{array}$ & $\begin{array}{c}-1.68 \\
(0.163)\end{array}$ & $\begin{array}{r}-6.285 \\
(2.678)\end{array}$ & $\begin{array}{c}90.402 \\
(20.342)\end{array}$ & 0.68 & 1.540 & 0.037 \\
\hline Philadelphia & $\begin{array}{c}0.018 \\
(0.009)\end{array}$ & $\begin{array}{c}-0.033 \\
(0.060)\end{array}$ & $\begin{array}{c}-0.190 \\
(0.492)\end{array}$ & $\begin{array}{l}59.717 \\
(6.033)\end{array}$ & 0.91 & 2.602 & 0.005 \\
\hline Pittsbur & $\begin{array}{c}0.023 \\
(0.006)\end{array}$ & $\begin{array}{c}-0.071 \\
(0.047)\end{array}$ & $\begin{array}{c}-0.229 \\
(0.104)\end{array}$ & $\begin{array}{l}13.477 \\
(1.157)\end{array}$ & 0.95 & 2.565 & 0,001 \\
\hline Portland & $\begin{array}{c}0.037 \\
(0.028)\end{array}$ & $\begin{array}{c}0.101 \\
(0.112)\end{array}$ & $\begin{array}{c}-0.231 \\
(0.363)\end{array}$ & $\begin{array}{c}9.942 \\
(1.274)\end{array}$ & 0.92 & 1.347 & 0.012 \\
\hline San Francisco & $\begin{array}{c}0.063 \\
(0.014)\end{array}$ & $\begin{array}{c}-0.052 \\
(0.077)\end{array}$ & $\begin{array}{c}-2.153 \\
(0.599)\end{array}$ & $\begin{array}{l}33.068 \\
(3.401)\end{array}$ & 0.90 & 1.592 & 0.003 \\
\hline Seattle & $\begin{array}{c}0.053 \\
(0.029)\end{array}$ & $\begin{array}{c}-0.002 \\
(0.085)\end{array}$ & $\begin{array}{c}-0.630 \\
(0.361)\end{array}$ & $\begin{array}{c}9.062 \\
(0.972)\end{array}$ & 0.93 & 1.883 & 0.009 \\
\hline Spokane & $\begin{array}{c}0.045 \\
(0.019)\end{array}$ & $\begin{array}{c}-0.015 \\
(0.075)\end{array}$ & $\begin{array}{c}-0.430 \\
(0.189)\end{array}$ & $\begin{array}{l}10.229 \\
(0.842)\end{array}$ & 0.94 & 1.959 & 0.006 \\
\hline
\end{tabular}

Notes. Standard errors are in parentheses. The dependent variable is the rate of change in rents.

behavior. First, the results suggest that vacancies play an important role in responding to demand fluctuations and in the setting of short-run prices. Second, the greater the number of vacancies, the greater the risk. ${ }^{15}$ Thus if vacancies become excessive, then instead of acting as a

\footnotetext{
${ }^{15}$ For well-diversified investors, the unsystematic portion of the change in vacancies can be
} 
buffer against unanticipated events, vacancies add to the risk of an investment. At the macro level, price should become more volatile as high levels of inventories cause risk characteristics to change.

\section{Normal Vacancy Rate}

The normal vacancy rate for each city is determined from the results reported in Table 1 by assuming that the intercept term in (1) is zero. In this case, the normal vacancy rate for each city is given by $V^{n}=b_{0} / b_{2}{ }^{16}$ Values of $\mathrm{V}^{\mathrm{n}}$ are shown in the last column of Table 2. Compared with the mean, standard deviation, and minimum and maximum values of $V$ for each city over the estimation period, the values of $V^{n}$ appear reasonable. A Chow test rejects the hypothesis that the coefficients in Table I are equal across cities at the $5 \%$ level. ${ }^{17}$

The level of $V^{\prime \prime}$ for each city should be correlated strongly with the information costs of arranging and leasing office space and the level of demand uncertainty prevailing in the market. On the demand side, inventory holdings of vacant office space serve an economic function to tenants by reducing the search costs of acquiring information about the stock of commercial office units available.

The normal level of vacancies also serves to reduce the costs of possible future relocations for firms. On the supply side, landlords facing stochastic demand are willing to invest in $V^{n}$ so that they are better positioned to take advantage of periods in which demand is higher than

diversified by investing in real estate projects in various parts of the nation. In general, business risk associated with real estate is determined by the type of project, its management, and its location.

${ }^{16}$ Assuming that the intercept term is zero violates one of the classical assumptions of least squares, namely that the error term has an expected value of zero. For least squares to be valid the constant term must absorb the mean effects of a number of variables. Alternatively, if it is assumed that the constant term is proportional to $b_{2}$ across cities, then $b_{0} / b_{2}$ equals the natural vacancy rate plus a constant. The constant can be explained away in the regressions that follow by the inclusion of an intercept term.

17 The formal statistical test in this case is an $F$ test on the pooled cross-section, time-series regression with city dummy variables, $D_{1} \ldots \ldots . ., D_{16}$ introduced for all but one of the cities. The results lead to an $F$ statistic of 29.7 , which is significant at the $5 \%$ level. 
normal. As mentioned previously, the extent of this investment depends on the landlord's marginal inventory costs. Finally, general economic conditions of the area should have an effect on $\mathrm{F}^{\mathrm{n}} .^{18}$

TABLE 2

Actual and Normal Vacancy Rates in Commercial Office Buildings by City, 1960-1975

\begin{tabular}{lrrrrr}
\hline \multicolumn{1}{c}{ City } & & & & & \\
Mean & SD & Minimum & Maximum & $\begin{array}{r}\text { Normal } \\
\text { vacancy } \\
\left(V^{\mathrm{n}}\right)^{a}\end{array}$ \\
\hline Atlanta & 5.83 & 2.66 & 2.40 & 13.50 & 6.32 \\
Baltimore & 5.93 & 3.05 & 2.64 & 11.86 & 13.91 \\
Chicago & 2.91 & 1.31 & 0.10 & 4.80 & 4.05 \\
Cleveland & 3.28 & 1.92 & 1.40 & 8.90 & 2.83 \\
Denver & 8.67 & 3.13 & 5.40 & 15.50 & 12.33 \\
Des Moines & 3.25 & 2.33 & 0.50 & 9.50 & 9.91 \\
Detroit & 7.95 & 3.10 & 2.70 & 14.05 & 11.79 \\
Indianapolis & 6.09 & 2.33 & 1.60 & 11.20 & 6.47 \\
Kansas City & 8.90 & 6.45 & 1.60 & 21.80 & 20.90 \\
Minneapolis & 3.77 & 1.69 & 1.60 & 8.00 & 4.48 \\
New York City & 0.51 & 0.67 & 0.00 & 1.90 & 1.00 \\
Philadelphia & 7.29 & 2.52 & 3.01 & 11.77 & 9.47 \\
Pittsburgh & 5.55 & 2.99 & 1.90 & 11.70 & 10.04 \\
Portland & 7.37 & 2.85 & 3.10 & 11.60 & 16.01 \\
San Francisco & 2.33 & 0.85 & 1.50 & 4.70 & 2.93 \\
Seattle & 8.38 & 2.75 & 4.70 & 14.00 & 8.41 \\
Spokane & 9.74 & 3.58 & 3.40 & 17.30 & 10.47 \\
\hline & & & & & \\
\hline
\end{tabular}

${ }^{a}$ The normal vacancy is calculated as $V^{\mathrm{n}}=b_{n} / b_{2}$ from Table 1.

In keeping with literature on the price-adjustment process for rental housing, we test the joint hypothesis that the normal vacancy rate, $V^{n}$,

\footnotetext{
${ }^{18}$ de Leeuw and Ekanem [11] argue that in areas of rapid construction, normal vacancy rates should be higher than those in other areas. For the rental housing market, Rosen and Smith [24] demonstrate that there is a positive relationship between normal vacancy rates and the average annual changes in the total housing stock.
} 
can be explained by the desire to react quickly to changes in demand and that variations in $V^{n}$ across cities follow from differences in the marginal costs of holding vacancy office space by estimating an equation of the form

$$
V^{\mathrm{n}}=v(\Delta K, \Delta \mathrm{NME}, \Delta \mathrm{POP}, \mathrm{PT}, \bar{R})
$$

where $V^{n}$ is the estimated normal vacancy rate in Table 2, $A K$ is the annual average change in the stock of office space in each metropolitan area during the period 1960 through 1970, $\triangle \mathrm{NME}$ is the change in nonmanufacturing employment from 1960 to 1970, $\triangle \mathrm{POP}$ is the change in metropolitan population from 1960 to 1970, PT is the average annual property tax rate for the period 1966 through 1976, and $\bar{R}$ is the average level of rent in each metropolitan area during the period 1960 through $1975^{19}$

The results of estimating (3) are

$$
\begin{gathered}
V^{\mathrm{n}}=-0.1014-\underset{(4.2441 E-07)}{6.8264 E-07 \Delta K}+\underset{(2.1856)}{2.9213 \Delta \mathrm{NME}} \\
+0.4823 \Delta \mathrm{POP}-1.1924 \mathrm{PT}-0.0054 \bar{R} \\
(0.7815) \quad(0.9652) \quad(0.0018) \\
N=17 \quad R^{2}=0.67
\end{gathered}
$$

where standard errors are in parentheses. While the equation fits the data well, given the small sample size, the fit is not as good as that obtained by Rosen and Smith [24] with their normal vacancy rate equation for rental housing.

19 The average change in office space was computed from biyearly estimates of office space construction as reported in "Skyline"; estimates of nonmanufacturing employment are from "Summary Characteristics for Governmental Units and SMSA's"; estimates of population are from "Census of Population and Housing" U.S. Department of Commerce, Bureau of the Census, various issues; PT is the Bureau of the Census estimate of the effective property tax rate for real property in selected local areas reported in the 1967 and 1977 "Census of Government," Table 20; $R$ is from BOMA. 
Consider first the negative and insignificant coefficient of $\Delta K$. The regression results suggest that the deLeeuw and Ekanem [11] hypothesis (supported by Rosen and Smith's [24] results), that the normal vacancy rate will be higher in areas of rapid rental housing construction, may not hold. This is a widely believed prediction regarding office markets. Instead the insignificant, but not weak, negative sign of the coefficient on the change in stock variable suggests that areas of rapid construction have lower than normal vacancy rates.

The two variables measuring expected demand, $\triangle \mathrm{NME}$ and $\triangle \mathrm{POP}$, have positive and insignificant coefficients. While little can be said about the effects of expected demand on normal vacancy since the signs of the coefficients of $\triangle \mathrm{NME}$ and $\triangle \mathrm{POP}$ are weak, their signs imply that normal vacancy rates are higher in periods of high expected demand. This is a common perception regarding the response of producers to an expected increase in aggregate demand.

The negative, but again insignificant, coefficient of PT is generally consistent with the hypothesis that an increase in the marginal costs of holding vacant units decreases the inventories landlords are willing to hold. The greater the current fixed operating cost for commercial office space, the greater the cost of holding vacant space, and hence the lower the normal vacancy rate.

The expected sign of $\bar{R}$ is ambiguous. On the one hand, an increase in $\bar{R}$ may represent an increase in the landlord's marginal opportunity cost of holding vacant units. On the other hand, tenants view vacant office space as a means of lowering their search cost. Since the coefficient of $\bar{R}$ is negative and significant, we interpret the results to mean that the effect of higher rents on landlord opportunity costs of holding inventories of vacant units exceeds the effect of higher rents on the cost of tenant search.

\section{CONCLUDING REMARKS}

Using revenue and expense data on office buildings for 17 cities, we 
examined the rent-adjustment process. Two separate tests were performed. The first was to relate rental changes and vacancies. The estimates suggest that variations in the vacancy rate around some desired vacancy rate are significant in determining price and output responses to changes in demand. From this specification, normal vacancy rates were calculated.

The second test was to explain variations in the normal vacancy rate across cities by differences in variables measuring expected growth in demand and supply of office space, and the marginal costs of holding inventories. The variables generally performed as expected. Reactions of output and prices to demand changes were strongest when the gap between desired and actual inventory holdings was largest. Inventory holding is also largest when the marginal costs of carrying inventories are lowest.

\section{REFERENCES}

[1] A. A. Alchian and W. R. Allen, "Exchange and Production," Wadsworth, Belmont, CA (1982).

[2] W. R. Archer, Determinants of location for general purpose office firms within medium size cities, AREUEA J., 9, 283-297 (1981).

[3] D. P. Baron, Price uncertainty, utility and industry equilibrium in pure competition, Int. Econom. Rev., 11, 463-480 (1970).

[4] A. S. Blinder, Inventories and sticky prices: More on the microfoundations of macroeconomics, Amer. Econom. Rev., 72, 334-348 (1982).

[5] A. S. Blinder and S. Fischer, Inventories, rational expectations, and the business cycle, J. Monet. Econom., 8, 277-304 (1981).

[6] T. P. Brennan, R. E. Cannaday, and P. F. Colwell, Office rent in the Chicago CBD, AREUEA J., 12, 295-305 (1984). 
[7] Building Owners and Managers Association International, Downtown and Suburban Office Building Experience Exchange Report, various years.

[8] D. R. Capozza, New evidence on rents and vacancies, working paper (1980).

[9] H. J. Cassidy, “Using Econometrics," Reston, Reston, VA (1981).

[10] J. M. Clapp, The intrametropolitan location of office activities, J. Reg. Sci., 20, 387-399 (1980).

[11] F. de Leeuw and N. F. Ekanem, The supply of rental housing, Amer. Econom. Rev., 61, 806-817 (1971).

[12] A. A. Eubank, Jr., and C. F. Simians, The price adjustment mechanism for rental housing in the United States, Q. J. Econom., 93, 163-183 (1979).

[13] G. Fallis and L. B. Smith, Uncontrolled prices in a controlled market: The case of rent controls, Amer. Econom. Rev., 74, 193-200 (1984).

[14] A. M. Hamer, Metropolitan planning and the location behavior of basic office firms: A case study, J. Reg. Sci., 4, 34-45 (1974).

[15] S. Karlin and C. Carr, Prices and optimal inventory policy, in "Studies in Applied Probabilities and Management Science (K. Arrow, Ed.), Stanford Univ. Press, Stanford, CA (1962).

[16] H. E. Leland, Savings and uncertainty: The precautionary demand for saving, Q. J. Econom., 82, 465-73 (1968).

[17] I. S. Lowry, Rental housing in the 1970s: Searching for the crisis, in "Rental Housing: Is There a Crisis" (J. C. Weicher, Ed.), The Urban Institute, Washington, DC (1981).

[18] L. J. Maccini, An aggregate dynamic model of short-run price and output behavior, Q. J. Econom. 90, 177-196 (1976).

[19] E. S. Mills, "Price, Output and Inventory Policy," Wiley, New York (1962).

[20] E. O. Olsen, An econometric analysis of rent control, J. Polit. 
Econom., 80, 1081-1100 (1972).

[21] L. Phlips, Intertemporal price discrimination and sticky prices, $Q$. J. Econom., 94, 525-542 (1980).

[22] R. S. Pindyck, Adjustment costs, uncertainty and the behavior of the firm, Amer. Econom. Rev., 72, 415-427 (1982).

[23] P. Rao and R. L. Miller, "Applied Econometrics," Wadsworth, Belmont, CA (1971).

[24] K. T. Rosen and L. B. Smith, The price adjustment process for rental housing and the natural vacancy rate, Amer. Econom. Rev., 73, 779-786 (1983).

[25] P. A. Samuelson, "The Foundations of Economic Analysis," Harvard Univ. Press, Cambridge, MA (1947).

[26] W. M. Shenkel, Net leases: A critical review, J. Prop. Manage., 27, 146-152 (1981).

[27] L. B. Smith, A note on the price adjustment mechanism for rental housing, Amer. Econom. Rev., 64, 478-481 (1974).

[28] H. Tauchen and A. D. Witte, Increased costs of office building operation and construction: Effects on the costs of office space and the equilibrium distribution of offices, Land Econom., 59, 324-336 (1983).

[29] E. Zabel, Multiperiod monopoly under uncertainty, J. Econom. Theory, 5, 524-36 (1972). 